\title{
APPLICATION OF TIME-COST-QUALITY-RISK TRADE-OFF MODEL IN MAGNETIC RESONANCE IMAGING MACHINE INSTALLATION PROJECT
}

\author{
S. C. Nwaneri ${ }^{1,}{ }^{*}$ and C. 0. Anyaeche ${ }^{2}$ \\ 1, DEPARTMENT OF BIOMEDICAL ENGINEERING, UNIVERSITY OF LAGOS, AKOKA-YABA, LAGOS STATE, NIGERIA \\ 2. DEPARTMENT OF INDUSTRIAL \& PRODUCTION ENGINEERING, UNIVERSITY OF IBADAN, OYo STATE, NIGERIA \\ E-mail addresses:1 ${ }^{1}$ snwaneri@unilag.edu.ng, ${ }^{2}$ osita.anyaeche@ui.edu.ng
}

\begin{abstract}
Effective project planning in Magnetic Resonance Imaging (MRI) machine installation takes into consideration several factors including Time, Cost, Quality and Risk which are essential but conflicting factors that affect projects. These critical factors should be optimized in all projects especially those in Low and Medium Income Countries (LMIC) with limited resources and inadequate investment in medical facilities and equipment. The main objective of this study was to develop an optimization model for fuzzy Time-Cost-Quality-Risk Trade-off (TCQRT) problem for MRI machine installation project. The model was solved by Multiobjective Genetic Algorithm (MOGA) and the solutions ranked using the Technique for the Order of Preferences by Similarity to Ideal Solution (TOPSIS). The results indicate a tradeoff relationship exists among time, cost, quality and risks.
\end{abstract}

Keywords: Time-Cost-Quality Trade-off Model, Magnetic Resonance Imaging, Multiobjective Genetic Algorithm

\section{INTRODUCTION}

Time, Cost, Quality and Risk are important metrics which affect the success of a project. Projects need to be completed in time, at acceptable cost, quality and minimal risk. The difficulty in optimizing these factors simultaneously led to the Time-Cost-Quality-Risk Trade-Off (TCQRT) problem [1, 2]. Studies by [3] showed that project crashing affects project quality. While in [4], it was suggested that risk could damage budget, time or resources. Therefore, the planning and organising stage of a project is important as quality is built in before the eventual take off of the project [5]. In Low and Medium Income Countries (LMIC) with inadequate investment in medical facilities and equipment, special efforts should be made in healthcare technology projects to optimize these factors. This will lead to improvement in customer satisfaction and reduction in conflict between stakeholders.

Trade-off problems between two or more metrics in project management have attracted considerable research interests [6-12]. The construction industry is the greatest beneficiary of research in this area [13 16]. However, a few studies have shown the application of such problems in healthcare projects [17 - 19]. In [17], the authors applied project scheduling techniques such as Critical Path Method (CPM), Programme Evaluation and Review Technique (PERT), and Graphical Evaluation Review Technique (GERT) to hospital-based Electronic Medical Records projects. In [18], the authors developed a Time-Cost-Risk (TCRT) model using Response Surface Methodology (RSM) for X-ray machine installation project. While in [19], the authors applied the TCQRT in neonatal incubator development project using Multiobjective Genetic Algorithm (MOGA) and fuzzy Technique For The Order of Preferences by Similarity to Ideal Solution (TOPSIS). In this study the TCQRT model was developed for Magnetic Resonance Imaging, (MRI) machine installation project.

Managers in industrial projects such as MRI machine installation projects are interested in reducing project duration using minimum resources at the best possible quality and at minimal risks. In this work, a fuzzy TimeCost-Quality-Risk trade-off model was developed so that project is carried out such that the time $T$, cost $C$ and Risks R, are minimized while quality $Q$ is maximized for the MRI machine installation project. Fuzziness is defined as the lack of distinction of an event [20].

The MRI machine is a highly efficient and very expensive non-ionising medical imaging device that 
makes use of radio waves and strong magnetic field to image the human body. It utilizes the principle of nuclear magnetic resonance (NMR) to image nuclei of atoms inside the body [21]. The major hardware components of an MRI device are the magnet, radiofrequency (RF), and gradient systems. The MRI technology has undergone significant transformations over the last two decades which is attributed to advances from the mathematical sciences and physics. In MRI imaging, the material imaged is the signal source. The core of an MRI apparatus is the magnet that generates the field for nuclear polarization. The equipment is very large and requires the construction of a building designed specifically to house the machine. The MRI machine installation project is capital intensive, with a high quality requirement and characterized by a high level of risk. Furthermore, it has been known to be highly efficient with superior imaging capability than most imaging techniques like Computed Tomography (CT) scan and X-ray.

Effective project management strategies need to be adopted in clinical engineering projects including the installation of medical imaging equipment such as the MRI machine installation project. Furthermore, the acquisition and deployment of medical equipment for use without adequate project management considerations may lead to early deterioration, malfunctioning and exposure to several risks [22]. In [23], the authors described the project planning and installation of a superconductive MRI machine at the Royal Adelaide Hospital, South Australia. They extensively discussed tender specification; assessment of offers and recommendations for a 10 Tesla unit. Due to the high cost of the equipment and project installation, the MRI machine is not affordable to most hospitals in developing countries. Hence, the project is rarely implemented in clinical engineering facilities of hospitals in developing countries. In addition, the installation conditions do vary from one location to the other. Consequently, precise project data or historical data may not be available for project planning purposes. In such imprecise project situations, the use of fuzzy data could be effective. This is the main thrust of this work. The aim of this study was to develop a fuzzy multi-criteria optimization model for TCQRTP for Magnetic Resonance Imaging (MRI) installation project using multi-objective genetic algorithm (MOGA).

\section{METHOD OF THE STUDY}

Data was obtained from the installation of a 15 Tesla Magnetic Resonance Imaging (MRI) project in a Hospital in South West, Nigeria. A structured questionnaire was filled by the lead engineer involved in the installation. Two execution modes were provided for each activity, while the actual installation were indicated as option 1 , values in option 2 represent the alternative modes for executing each activity. Due to the imprecise nature of data available fuzzy variables were assigned to each project activity using Triangular Fuzzy Numbers (TFNs) representing the minimum, most likely and maximum values for each objective [24]. Time was measured in days, Cost in Naira ( $($ ), the Quality on a scale of $0-100 \%$ while Risk was measured on a scale of $0-1$. Qualitative risk assessment was achieved using fuzzy risk probability and impact tables as shown in Tables 1 and 2 respectively. Table 1 shows the qualitative fuzzy risk probability ranked in 5 categories: Certain, Very Likely, Likely, Unlikely, and Rare. While Table 2 presents the qualitative risk impact ranked also in 5 categories: Extremely High, High, moderate, low, and extremely low.

Table 1: Qualitative Description of Risk Probability

\begin{tabular}{lll}
\hline Risk Probability & Range of Fuzzy Values & Description \\
\hline Certain (C) & $(0.8,0.9,1.00)$ & Almost certain to happen \\
Very Likely Cases (VL) & $(0.6,0.7,0.8)$ & Very likely to happen in most cases \\
Likely (L) & $(0.4,0.5,0.6)$ & Likely to happen in some cases \\
Unlikely (U) & $(0.3,0.4,0.5)$ & Unlikely to happen in most cases \\
Rare (R) & $(0.2,0.3,0.4)$ & Occurs in exceptional cases \\
\hline
\end{tabular}

Table 2: Qualitative Description of Risk Impact

\begin{tabular}{lll}
\hline Risk Impact & Range of Fuzzy Values & Description \\
\hline Extremely High (EH) & $(0.8,0.9,1.00)$ & Severe impact on project objectives \\
High (H) & $(0.6,0.7,0.8)$ & High impact on project objectives \\
Moderate (M) & $(0.4,0.5,0.6)$ & Moderate impact on project objectives \\
Low (LW) & $(0.3,0.4,0.5)$ & Insignificant impact on project objectives \\
Extremely Low (EL) & $(0.2,0.3,0.4)$ & Extremely insignificant impact on project objectives \\
\hline
\end{tabular}


Table 3: Fuzzy Risk for Project Activities

\begin{tabular}{|c|c|c|c|c|c|}
\hline $\begin{array}{l}\text { Act } \\
\text { ID }\end{array}$ & Description of Activity & $\begin{array}{l}\text { Fuzzy Risk } \\
\text { Probability }\end{array}$ & $\begin{array}{l}\text { Fuzzy Risk } \\
\text { Impact }\end{array}$ & Fuzzy Risk & $\begin{array}{l}\text { Defuzzified } \\
\text { Risk Rating }\end{array}$ \\
\hline \multirow[t]{2}{*}{1} & \multirow[t]{2}{*}{ Site Selection } & $0.2,0.3,0.4$ & $0.4,0.5,0.6$ & $0.08,0.15,0.24$ & 0.16 \\
\hline & & $0.2,0.3,0.4$ & $0.4,0.5,0.6$ & $0.08,0.15,0.24$ & 0.16 \\
\hline \multirow[t]{2}{*}{2} & \multirow[t]{2}{*}{ Construction Drawings } & $0.4,0.5,0.6$ & $0.2,0.3,0.4$ & $0.08,0.15,0.24$ & 0.16 \\
\hline & & $0.4,0.5,0.6$ & $0.2,0.3,0.5$ & $0.08,0.15,0.30$ & 0.18 \\
\hline \multirow[t]{2}{*}{3} & \multirow[t]{2}{*}{ Building Construction } & $0.2,0.3,0.4$ & $0.2,0.3,0.4$ & $0.04,0.09,0.16$ & 0.10 \\
\hline & & $0.3,0.4,0.5$ & $0.3,0.4,0.5$ & $0.09,0.16,0.25$ & 0.17 \\
\hline \multirow[t]{2}{*}{4} & \multirow{2}{*}{$\begin{array}{l}\text { Pre-Installation Tests, Room } \\
\text { preparation civil works }\end{array}$} & $0.2,0.3,0.4$ & $0.2,0.3,0.4$ & $0.04,0.09,0.16$ & 0.10 \\
\hline & & $0.3,0.4,0.5$ & $0.3,0.4,0.5$ & $0.09,0.12,0.15$ & 0.12 \\
\hline \multirow[t]{2}{*}{5} & \multirow{2}{*}{$\begin{array}{l}\text { Electrical Infrastructure } \\
\text { Installations/UPS Inst. }\end{array}$} & $0.6,0.7,0.8$ & $0.6,0.7,0.8$ & $0.36,0.49,0.64$ & 0.50 \\
\hline & & $0.6,0.7,0.8$ & $0.6,0.7,0.8$ & $0.36,0.49,0.64$ & 0.50 \\
\hline \multirow[t]{2}{*}{6} & \multirow{2}{*}{$\begin{array}{l}\text { Mechanical Infrastructure } \\
\text { Installations }\end{array}$} & $0.6,0.7,0.8$ & $0.8,0.9,1.00$ & $0.48,0.63,0.80$ & 0.63 \\
\hline & & $0.6,0.7,0.8$ & $0.7,0.8,1.00$ & $0.42,0.56,0.80$ & 0.59 \\
\hline \multirow[t]{2}{*}{7} & \multirow[t]{2}{*}{ Water Supply installations } & $0.6,0.7,0.8$ & $0.8,0.9,1.00$ & $0.48,0.63,0.80$ & 0.63 \\
\hline & & $0.6,0.7,0.8$ & $0.8,0.9,1.00$ & $0.48,0.63,0.80$ & 0.63 \\
\hline \multirow[t]{2}{*}{8} & \multirow{2}{*}{$\begin{array}{l}\text { Design and Fabrication of Cryogen } \\
\text { Vent }\end{array}$} & $0.4,0.5,0.6$ & $0.6,0.7,0.80$ & $0.24,0.35,0.48$ & 0.35 \\
\hline & & $0.4,0.5,0.6$ & $0.6,0.7,0.80$ & $0.24,0.35,0.48$ & 0.35 \\
\hline \multirow[t]{2}{*}{9} & \multirow[t]{2}{*}{ RF Shielding } & $0.4,0.5,0.6$ & $0.8,0.9,1.00$ & $0.32,0.45,0.60$ & 0.45 \\
\hline & & $0.4,0.5,0.6$ & $0.8,0.9,1.00$ & $0.32,0.45,0.60$ & 0.45 \\
\hline \multirow[t]{2}{*}{10} & \multirow{2}{*}{$\begin{array}{l}\text { Radiation Testing/Power and } \\
\text { Grounding /MRI room Validation }\end{array}$} & $0.4,0.5,0.6$ & $0.8,0.9,1$ & $0.32,0.45,0.60$ & 0.45 \\
\hline & & $0.4,0.5,0.6$ & $0.8,0.9,1.00$ & $0.32,0.45,0.60$ & 0.45 \\
\hline \multirow[t]{2}{*}{11} & \multirow[t]{2}{*}{ MRI Machine Delivery } & $0.6,0.7,0.8$ & $0.8,0.9,1.00$ & $0.48,0.63,0.80$ & 0.63 \\
\hline & & $0.6,0.7,0.8$ & $0.8,0.9,1.00$ & $0.48,0.63,0.80$ & 0.63 \\
\hline \multirow[t]{2}{*}{12} & \multirow[t]{2}{*}{ MRI Machine Installation } & $0.8,0.9,1.00$ & $0.8,0.9,1.00$ & $0.64,0.81,1.00$ & 0.81 \\
\hline & & $0.8,0.9,1.00$ & $0.8,0.9,1.00$ & $0.72,0.81,1.00$ & 0.83 \\
\hline \multirow[t]{2}{*}{13} & \multirow[t]{2}{*}{ Calibration and Testing } & $0.8,0.9,1.00$ & $0.8,0.9,1.00$ & $0.64,0.81,1.00$ & 0.81 \\
\hline & & $0.8,0.9,1.00$ & $0.8,0.9,1.00$ & $0.64,0.81,1.00$ & 0.81 \\
\hline \multirow[t]{2}{*}{14} & \multirow[t]{2}{*}{ Applications Training } & $0.6,0.7,0.8$ & $0.6,0.7,0.8$ & $0.36,0.49,0.64$ & 0.50 \\
\hline & & $0.6,0.7,0.8$ & $0.6,0.7,0.8$ & $0.36,0.49,0.64$ & 0.50 \\
\hline \multirow[t]{2}{*}{15} & \multirow[t]{2}{*}{ Commissioning and Close out } & $0.2,0.3,0.4$ & $0.2,0.3,0.4$ & $0.04,0.09,0.16$ & 0.10 \\
\hline & & $0.2,0.3,0.4$ & $0.2,0.3,0.4$ & $0.04,0.09,0.16$ & 0.10 \\
\hline
\end{tabular}

The value of risk for each activity was calculated based on the product of fuzzy risk probability and impact which was defuzzified as presented in Table 3.
Defuzzification method adopted was the centroid defuzzification (1) [20]:

$$
z^{*}=\frac{\int \mu_{\mathrm{z}}(\mathrm{z}) \cdot \mathrm{zdz}}{\int \mu_{\mathrm{z}}(\mathrm{z}) \cdot \mathrm{dz}}
$$


where $\int$ represents algebraic integration. Values of different options of risk are calculated as definite integrals and further simplified in (2) where a, b, c denote the minimum, medium and maximum values for risk of each activity.

$$
z^{*}=\left[\frac{\int_{a}^{\mathrm{b}}(\mathrm{z}) \mathrm{zdz}+\int_{b}^{c}(\mathrm{z}) \mathrm{zdz}}{\int_{\mathrm{a}}^{\mathrm{b}}(\mathrm{z}) \mathrm{dz}+\int_{b}^{\mathrm{c}}(\mathrm{z}) \mathrm{dz}}\right]
$$

The MRI machine installation project is affected by different types of risk including technical, operational, economic and financial risks, environmental and safety risks. Due to the presence of strong magnetic field caused by the magnets in the machine, special care is taken to prevent the attraction of other devices to the equipment which may lead to one form of injury or the other. Furthermore, radiofrequency signals from the installation may affect equipment from other electronic devices worn by those within the vicinity of the installation. The fuzzy and crisp work packages for the entire project are shown in Tables 4 and 5 respectively.

Table 4: Fuzzy Work Package for Magnetic Resonance Imaging Machine Installation

\begin{tabular}{|c|c|c|c|c|c|c|}
\hline $\begin{array}{l}\text { Act. } \\
\text { ID }\end{array}$ & Description of Activity & Pre. & $\begin{array}{l}\text { Fuzzy Time } \\
\text { (days) }\end{array}$ & $\begin{array}{l}\text { Fuzzy Cost } \\
\text { (N) }\end{array}$ & Quality & Risk \\
\hline \multirow{2}{*}{1} & \multirow{2}{*}{ Site Selection } & \multirow{2}{*}{-} & $6,7,8$ & No charges & 99.00 & 0.16 \\
\hline & & & $6,7,8$ & No charges & 99.00 & 0.16 \\
\hline \multirow{2}{*}{2} & \multirow{2}{*}{ Construction Drawings } & \multirow{2}{*}{1} & $10,15,15$ & $3046,4061,5076$ & 99.00 & 0.16 \\
\hline & & & $9,13,13$ & $3249,4467,5076$ & 99.00 & 0.18 \\
\hline \multirow{2}{*}{3} & \multirow{2}{*}{ Building Construction } & \multirow{2}{*}{2} & $50,58,66$ & $13503,44670,55838$ & 99.00 & 0.10 \\
\hline & & & $30,90,90$ & $30457,40609,50761$ & 99.00 & 0.17 \\
\hline \multirow{2}{*}{4} & \multirow{2}{*}{$\begin{array}{l}\text { Pre-Installation Tests, Room } \\
\text { preparation civil works }\end{array}$} & \multirow{2}{*}{3} & $12,14,16$ & $1015,1269,1523$ & 99.00 & 0.10 \\
\hline & & & $10,12,14$ & $1218,1371,1599$ & 99.00 & 0.12 \\
\hline \multirow{2}{*}{5} & \multirow{2}{*}{$\begin{array}{l}\text { Electrical Infrastructure } \\
\text { Installations/UPS Inst. }\end{array}$} & \multirow{2}{*}{4} & $2,3,4$ & $2031,2284,2538$ & 99.00 & 0.50 \\
\hline & & & $2,3,4$ & $2031,2284,2538$ & 99.00 & 0.50 \\
\hline \multirow{2}{*}{6} & \multirow{2}{*}{$\begin{array}{l}\text { Mechanical Infrastructure } \\
\text { Installations }\end{array}$} & \multirow{2}{*}{5} & $3,5,7$ & $1523,1777,2031$ & 99.00 & 0.63 \\
\hline & & & $3,4,5$ & $1675,1827,2091$ & 98.50 & 0.59 \\
\hline \multirow{2}{*}{7} & \multirow{2}{*}{ Water Supply installations } & \multirow{2}{*}{6} & $3,5,7$ & $1015,1269,1522$ & 99.00 & 0.63 \\
\hline & & & $2,4,6$ & $1142,1289,1564$ & 98.50 & 0.63 \\
\hline \multirow{2}{*}{8} & \multirow{2}{*}{$\begin{array}{l}\text { Design and Fabrication of } \\
\text { Cryogen Vent }\end{array}$} & \multirow{2}{*}{7} & $4,5,6$ & $1269,1522,1777$ & 99.00 & 0.35 \\
\hline & & & $2,4,6$ & $1447,1574,1777$ & 98.50 & 0.35 \\
\hline \multirow{2}{*}{9} & \multirow{2}{*}{ RF Shielding } & \multirow{2}{*}{8} & $12,14,16$ & No charges & 99.00 & 0.45 \\
\hline & & & $12,14,16$ & No charges & 99.00 & 0.45 \\
\hline \multirow[b]{2}{*}{10} & \multirow{2}{*}{$\begin{array}{l}\text { Radiation Testing/Power and } \\
\text { Grounding /MRI room } \\
\text { Validation }\end{array}$} & \multirow[b]{2}{*}{9} & $10,12,14$ & $355,381,406$ & 99.00 & 0.45 \\
\hline & & & $8,10,12$ & $399,411,447$ & 99.00 & 0.45 \\
\hline 11 & MPI Machine Dolivery & 10 & $40,60,80$ & $2031,2284,2538$ & 99.00 & 0.63 \\
\hline 11 & 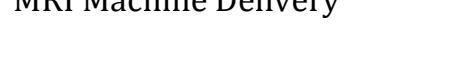 & 10 & $40,60,80$ & $2031,2284,2538$ & 99.00 & 0.63 \\
\hline 12 & & 11 & $5,8,10$ & $50761,76142,101522$ & 99.00 & 0.81 \\
\hline 12 & MRI Machıne Installation & 11 & $5,6,9$ & $63452,76142,111675$ & 98.50 & 0.83 \\
\hline 12 & Colibrotion ond Tocting & 12 & $1,2,3$ & No charges & 99.00 & 0.81 \\
\hline 13 & Campracion and resting & 13 & $1,2,3$ & No charges & 99.00 & 0.81 \\
\hline 14 & Annlicotions Trnining & 11 & $5,5,5$ & No charges & 99.00 & 0.50 \\
\hline 14 & Appincacions irammg & 14 & $5,5,5$ & No charges & 99.00 & 0.50 \\
\hline 15 & Commiccioning ond Cloce out & 15 & 1,11 & No charges & 99.00 & 0.10 \\
\hline 15 & Commissioning ana ciose out & 15 & $1,1,1$ & No charges & 99.00 & 0.10 \\
\hline
\end{tabular}


Table 5: Crisp Work Package for Magnetic Resonance Imaging Machine Installation

\begin{tabular}{|c|c|c|c|c|c|c|}
\hline $\begin{array}{l}\text { Act } \\
\text { ID }\end{array}$ & Description of Activity & Pred. & $\begin{array}{l}\text { Time } \\
\text { (days) }\end{array}$ & $\begin{array}{l}\text { Cost } \\
\text { (\#) }\end{array}$ & Quality & Risk \\
\hline \multirow[t]{2}{*}{1} & \multirow[t]{2}{*}{ Site Selection } & & 7.00 & No Charges & 99.00 & 0.16 \\
\hline & & & 7.00 & No Charges & 99.00 & 0.16 \\
\hline \multirow[t]{2}{*}{2} & \multirow[t]{2}{*}{ Construction Drawings } & \multirow[t]{2}{*}{1} & 12.00 & 4,061 & 99.00 & 0.16 \\
\hline & & & 11.00 & 4,264 & 99.00 & 0.18 \\
\hline \multirow[t]{2}{*}{3} & \multirow[t]{2}{*}{ Building Construction } & \multirow[t]{2}{*}{2} & 60.00 & 40,609 & 99.00 & 0.10 \\
\hline & & & 58.00 & 44,670 & 98.00 & 0.12 \\
\hline \multirow[t]{2}{*}{4} & \multirow{2}{*}{$\begin{array}{l}\text { Pre-Installation Tests, Room } \\
\text { preparation civil works }\end{array}$} & \multirow[t]{2}{*}{3} & 14.00 & 1,396 & 99.00 & 0.10 \\
\hline & & & 12.00 & 1,396 & 98.00 & 0.12 \\
\hline \multirow[t]{2}{*}{5} & \multirow{2}{*}{$\begin{array}{l}\text { Electrical Infrastructure } \\
\text { Installations/UPS Inst. }\end{array}$} & \multirow[t]{2}{*}{4} & 3.00 & 2,284 & 99.00 & 0.50 \\
\hline & & & 3.00 & 2,284 & 99.00 & 0.50 \\
\hline \multirow[t]{2}{*}{6} & \multirow[t]{2}{*}{ Mechanical Infrastructure Installations } & \multirow[t]{2}{*}{5} & 5.00 & 1,777 & 99.00 & 0.63 \\
\hline & & & 4.00 & 1,863 & 98.50 & 0.65 \\
\hline \multirow[t]{2}{*}{7} & \multirow[t]{2}{*}{ Water Supply installations } & \multirow[t]{2}{*}{6} & 5.00 & 1,269 & 99.00 & 0.63 \\
\hline & & & 4.00 & 1,333 & 98.50 & 0.65 \\
\hline \multirow[t]{2}{*}{8} & \multirow{2}{*}{$\begin{array}{l}\text { Design and Fabrication of Cryogen } \\
\text { Vent }\end{array}$} & \multirow[t]{2}{*}{7} & 5.00 & 1,553 & 99.00 & 0.35 \\
\hline & & & 4.00 & 1,599 & 98.50 & 0.37 \\
\hline \multirow[t]{2}{*}{9} & \multirow{2}{*}{ RF Shielding } & \multirow[t]{2}{*}{9} & 14.00 & No Charges & 99.00 & 0.45 \\
\hline & & & 14.00 & No Charges & 99.00 & 0.45 \\
\hline \multirow[t]{2}{*}{10} & \multirow{2}{*}{$\begin{array}{l}\text { Radiation Testing/Power and } \\
\text { Grounding /MRI room Validation }\end{array}$} & \multirow[t]{2}{*}{9} & 12.00 & 381 & 99.00 & 0.45 \\
\hline & & & 10.00 & 419 & 99.00 & 0.45 \\
\hline \multirow[t]{2}{*}{11} & MRI Machine Delivery & 11 & 60.00 & 2,284 & 99.00 & 0.63 \\
\hline & & & 60.00 & 2,284 & 99.00 & 0.63 \\
\hline 12 & MRI Machine Installation & 12 & 7.65 & 76,142 & 99.00 & 0.81 \\
\hline & & & 6.65 & 83,756 & 98.50 & 0.83 \\
\hline 13 & Calibration and Testing & 12 & 2.00 & No Charges & 99.00 & 0.81 \\
\hline & & & 2.00 & No Charges & 99.00 & 0.81 \\
\hline 14 & Applications Training & 13 & 5.00 & No Charges & 99.00 & 0.50 \\
\hline & & & 5.00 & No Charges & 99.00 & 0.50 \\
\hline 15 & Commissioning and Close out & 14 & 1.00 & No Charges & 99.00 & 0.10 \\
\hline & & & 1.00 & No Charges & 99.00 & 0.10 \\
\hline
\end{tabular}

The model was developed by making the following assumptions:

1. The time, cost, quality and risk variables are fuzzy.

2. The precedence network is based on the Finish-toStart activity relationship.

3. The quality of an activity will not fall below its minimum quality requirement.

4. Each activity of the project is characterized by a certain level of risk.

5. The risk of each activity is the product of the fuzzy probability and impact of each activity.
The model consists of the following objective functions and constraints as follows:

$$
\begin{gathered}
\operatorname{Min} \mathrm{T}=\sum_{\mathrm{i}=1}^{\mathrm{n}} \tilde{\mathrm{t}}_{\mathrm{ij}} \mathrm{x}_{\mathrm{ij}} \\
\operatorname{Min} \mathrm{C}=\sum_{\mathrm{i}=1}^{\mathrm{n}} \tilde{\mathrm{c}}_{\mathrm{ij}} \mathrm{x}_{\mathrm{ij}}+\mathrm{TC}_{\mathrm{d}} \\
\operatorname{Max} \mathrm{Q}=\frac{\sum_{\mathrm{i}=1}^{\mathrm{N}} \mathrm{q}_{\mathrm{ij}} \mathrm{x}_{\mathrm{ij}}}{\mathrm{N}} \\
\operatorname{Min} \mathrm{R}=\sum_{\mathrm{i}=}^{\mathrm{n}} \frac{\tilde{\mathrm{r}}_{\mathrm{ij}}}{\mathrm{N}}
\end{gathered}
$$


Subject to:

Subject to the precedence, execution mode, and nonnegativity constraints respectively as shown in (7) (9).

$$
\begin{aligned}
& A_{s}-A_{p} \geq \tilde{t}_{i j} x_{i j} \\
& \sum_{i=1}^{N} x_{i j}=1 \\
& t_{i j}, c_{i j}, C_{d}, q_{i j} \text { and } r_{i j} \geq 0
\end{aligned}
$$

The index variable, $x_{i j}$, is a binary variable for performing $i^{\text {th }}$ activity in $\mathrm{j}$ mode. $\mathrm{A}_{s}$ and $\mathrm{A}_{\mathrm{p}}$ represent the succeeding and preceding activities respectively. Equation (3) minimizes the total project duration $\mathrm{T}$, by summing the project duration for each activity $t_{i j}$ on the critical path. Equation (4) minimizes the total cost of the project comprising direct and indirect costs respectively, where $C_{d}$, is the daily indirect cost. Equation (5) maximizes the mean quality of the project and (6) minimizes the mean risk of the project.

The developed model was solved using Multi-Objective Genetic Algorithm (MOGA) which is an improvement on the single GA developed by Fonseca and Fleming [25]. The algorithm provides multiple Pareto optimal solutions for the objectives of the multiobjective optimization problem in a single simulation run [26]. The MOGA also utilizes elite preservation strategy to improve the chances of obtaining global optimum results. Parameter settings for MOGA are presented in Table 6.

Table 6: Parameter Settings

\begin{tabular}{ll}
\hline Parameter & Value \\
\hline Population & 30 \\
Generation & 100 \\
Crossover & Single Point Crossover \\
Mutation & Random \\
Mutation Rate & 0.25 \\
Crossover Fraction & 0.7 \\
Distance Measurement & Distance Crowding \\
\hline
\end{tabular}

The process begins with the encoding of chromosomes using integer encoding with the number of genes representing the number of project activities, while the position of the genes represents the project execution mode. Thereafter, an initial random population set at 30 chromosomes was generated. The fitness of the chromosomes was evaluated. The algorithm was implemented as a weighted sum of multiple objective functions and combined into a scalar fitness function. The weights were randomly specified for each selection as shown in (10).

$\mathrm{f}=\mathrm{w}_{1} \mathrm{~T}_{\text {norm }}+\mathrm{w}_{2} \mathrm{C}_{\text {norm }}-\mathrm{w}_{3} \mathrm{Q}_{\text {norm }}+\mathrm{w}_{4} \mathrm{R}_{\text {norm }}$ (10)

Given that $\mathrm{T}_{\text {norm }}, \mathrm{C}_{\text {norm }}, \mathrm{Q}_{\text {norm }}$ and $\mathrm{R}_{\text {norm }}$ are normalized values for the objective functions of time, cost, quality and risk respectively obtained by dividing each solution with the maximum value for each corresponding objective function as presented in (11) to (14), while the algebraic sum of the weights is equal to 1 as presented in (15). The value of each weight is 0.25 .

$$
\begin{aligned}
& \mathrm{T}_{\text {norm }}=\frac{\mathrm{T}_{n}}{\mathrm{~T}_{\max }} \\
& \mathrm{C}_{\text {norm }}=\frac{\mathrm{C}_{\mathrm{n}}}{\mathrm{C}_{\max }} \\
& \mathrm{Q}_{\text {norm }}=\frac{\mathrm{Q}_{\mathrm{n}}}{\mathrm{Q}_{\max }} \\
& \mathrm{R}_{\text {norm }}=\frac{\mathrm{R}_{n}}{\mathrm{R}_{\max }} \\
& \mathrm{w}_{1}+\mathrm{w}_{2}+\mathrm{w}_{3}+\mathrm{w}_{4}=1
\end{aligned}
$$

The fittest chromosomes for each generation were selected. The process involves storing some sets of Pareto optimal solutions in each generation. Selected parents were paired for mating as information between paired parents were exchanged using one point crossover. Random mutation was used to alter the value of one or more genes contained in a chromosome at a mutation rate of 0.25 . Mutation prevents premature convergence.

The solutions obtained were ranked using the TOPSIS based on the principle that the solution selected is nearest to the positive ideal solution and farthest from the negative ideal solution [27]. The TOPSIS was chosen as a multiple criteria decision making (MCDM) method because it is a simpler, easier and useful technique for ranking and selection of a number of alternatives through distance measures [28]. The TOPSIS algorithm for ranking the solutions include:

Step 1: Construct a decision matrix using the Pareto optimal solutions

$$
S=\left[\begin{array}{cccc}
t_{1} & c_{1} & q_{1} & r_{1} \\
t_{2} & c_{2} & q_{2} & r_{2} \\
t_{3} & c_{3} & q_{3} & r_{3} \\
& & \cdot & \\
& & \cdot & \\
t_{N} & c_{N} & q_{N} & r_{N}
\end{array}\right]
$$

Step 2: Normalize the decision matrix as shown in (17).

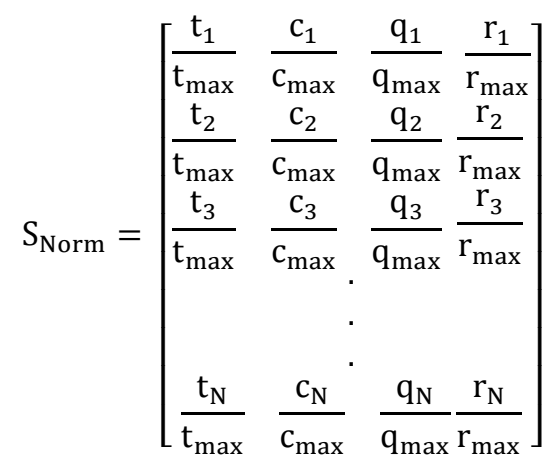


Step 3: Construct a weighted normalised decision matrix as shown in (18).

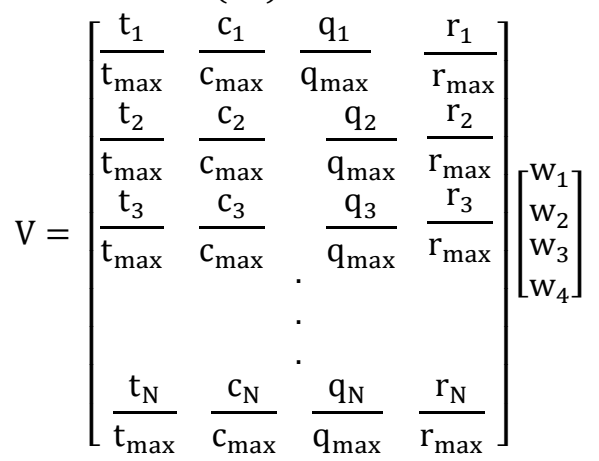

Equation (18) can be simplified as:

$$
\mathrm{V}=\left[\begin{array}{rrrr}
\mathrm{v}_{11} & \mathrm{v}_{12} & \mathrm{v}_{13} & \mathrm{v}_{14} \\
\mathrm{v}_{21} & \mathrm{v}_{22} & \mathrm{v}_{23} & \mathrm{v}_{24} \\
\mathrm{v}_{31} & \mathrm{v}_{32} & \mathrm{v}_{33} & \mathrm{v}_{34} \\
& \cdot & & \\
& \cdot & & \\
\mathrm{v}_{\mathrm{N} 1} & \mathrm{v}_{\mathrm{N} 2} & \mathrm{v}_{\mathrm{N} 3} & \mathrm{v}_{\mathrm{N} 4}
\end{array}\right]
$$

Step 4: Construct the Positive Ideal Solution

The Positive Ideal Solution is represented in (20) and (21) for minimization and maximization problems respectively

$$
\mathrm{V}_{\mathrm{J}}^{+}=\min \left\{\mathrm{v}_{\mathrm{ij}}\right\} \quad \text { for minimization problem }
$$

or

$$
\mathrm{V}_{\mathrm{J}}^{+}=\max \left\{\mathrm{v}_{\mathrm{ij}}\right\} \quad \text { for maximization problem }
$$

Step 5: Construct the Negative Ideal Solution The negative Ideal solutions are given by (22) and (23) for minimization and maximization problems respectively.

$$
\mathrm{V}_{\mathrm{j}}^{-}=\max \left\{\mathrm{v}_{\mathrm{ij}}\right\} \text { for minimization problems }
$$

or

$$
\mathrm{V}_{\mathrm{j}}^{-}=\min \left\{\mathrm{v}_{\mathrm{ij}}\right\} \text { for maximization problem }
$$

Step 6: Calculate the Distance of Weighted Alternative from the Positive and Negative Ideal Solution
The right and left distance of each weighted alternative from the positive and negative ideal solutions were calculated as shown in (24) and (25) respectively.

$$
\begin{aligned}
& \mathrm{S}_{\mathrm{i}}^{+}=\left[\sum\left(\mathrm{v}_{\mathrm{j}}^{+}-\mathrm{v}_{\mathrm{ij}}\right)^{2}\right]^{1 / 2} \\
& \mathrm{~S}_{\mathrm{i}}^{-}=\left[\sum\left(\mathrm{v}_{\mathrm{j}}^{-}-\mathrm{v}_{\mathrm{ij}}\right)^{2}\right]^{1 / 2}
\end{aligned}
$$

Step 7: Calculate the Closeness Coefficient

$$
\mathrm{cc}_{\mathrm{i}}=\frac{\mathrm{S}_{\mathrm{i}}^{-}}{\mathrm{S}_{\mathrm{i}}^{+}+\mathrm{S}_{\mathrm{i}}^{-}}
$$

Finally, the closeness coefficient was given by the ratio of these relative distances from the positive and negative ideal solutions respectively [27] as shown in (26). The Pareto optimal solution with the highest Closeness Coefficient (CC) value was chosen as the best alternative.

\section{RESULTS AND DISCUSSION}

Deterministic TCQRT problem was investigated by some researchers [1, 2]. However, in real life situations it is difficult to precisely estimate the Time, Cost, Quality and Risk of each project activity. The consideration of fuzzy numbers in trade-off problems has been found to be appropriate for vague situations in real life projects especially in project situations that lack historical data [24]. Authors have also suggested that fuzzy numbers are more effective in project networks to determine project duration of cost in real life project networks [29]. In LMIC, there are several technical difficulties associated with technology based projects like MRI installation which make it difficult to provide precise values for the project duration, cost of installation, quality and associated risks. Hence, the use of fuzzy numbers is appropriate in such situations. Table 7 shows the various combinations of time, cost, quality and risk, which represent various options available for the execution of the project and their corresponding closeness coefficient (CC) ranked in decreasing order.

Table 7: Results for Magnetic Resonance Imaging Installation Project

\begin{tabular}{lllllll}
\hline S/N & $\begin{array}{l}\text { Time } \\
\text { (Days })\end{array}$ & Cost $(\$ 1,000)$ & $\begin{array}{l}\text { Quality } \\
(\%)\end{array}$ & Risk & $\begin{array}{l}\text { Closeness } \\
\text { Coefficient }\end{array}$ & $\begin{array}{l}\text { Resource Option for Each } \\
\text { Activity }\end{array}$ \\
\hline 1 & 129 & $136,254.00$ & 98.77 & 0.4333 & 0.7664 & 111111111212111 \\
2 & 132 & $136,170.00$ & 98.80 & 0.4320 & 0.7043 & 11111111111111 \\
3 & 133 & $136,106.00$ & 98.83 & 0.4307 & 0.6725 & 122212111111111 \\
4 & 134 & $136,020.00$ & 98.87 & 0.4293 & 0.6397 & 122212221212111 \\
5 & 134 & $136,020.00$ & 98.93 & 0.4280 & 0.6389 & 111111221212111 \\
6 & 138 & $131,959.00$ & 99.00 & 0.4267 & 0.6014 & 111112221212111 \\
7 & 131 & $139,604.00$ & 98.80 & 0.4320 & 0.5942 & 122111111111111 \\
8 & 139 & $131,756.00$ & 99.00 & 0.4253 & 0.5785 & 111212221212111 \\
9 & 133 & $139,518.00$ & 98.90 & 0.4293 & 0.5488 & 121111111111111 \\
\hline
\end{tabular}




\begin{tabular}{lllllll}
\hline S/N & $\begin{array}{l}\text { Time } \\
\text { (Days) }\end{array}$ & Cost $(\$ 1,000)$ & $\begin{array}{l}\text { Quality } \\
(\%)\end{array}$ & Risk & $\begin{array}{l}\text { Closeness } \\
\text { Coefficient }\end{array}$ & $\begin{array}{l}\text { Resource Option for Each } \\
\text { Activity }\end{array}$ \\
\hline 10 & 133 & $139,604.00$ & 98.87 & 0.4307 & 0.5452 & 122212211111111 \\
11 & 128 & $143,868.00$ & 98.73 & 0.4347 & 0.5260 & 122212221111111 \\
12 & 129 & $143,665.00$ & 98.73 & 0.4333 & 0.5151 & 122212221211111 \\
13 & 135 & 139.454 .00 & 98.93 & 0.4280 & 0.4972 & 122211111111111 \\
14 & 136 & $139,408.00$ & 98.97 & 0.4267 & 0.4746 & 112212221212111 \\
15 & 130 & $143,830.00$ & 93.73 & 0.4347 & 0.3937 & 111111121212111 \\
\hline
\end{tabular}

The preferred solutions are those with higher CC values. It can be observed that option 1 , is the dominating option for the solutions with high CC values. The optimal time, cost, quality, and risk were 128 days, $\$ 131,756.00,99 \%$ and 0.4253 respectively. The best observed CC value was 0.7664 for the solution set [129 days, $\$ 136254.00,98.77 \%$, and 0.4333]. However, the worst CC value observed was 0.3937 for the solution set [130 days, N143830.00, 93.73\%, 0.4347]. The decision maker may prefer one objective over the others. Hence, he may choose the solution set with the desired optimal value of that objective. For instance, if the intention of the decision maker is to choose the solution with minimum time, the solution set [128 days, $\$ 143868.00,98.73 \%$ and 0.4347$]$ will be the best option.

Optimal project duration could be achieved by ensuring that project activities on the critical path are accomplished using the options with minimal project durations.

\subsection{Hypothesis Testing}

Null Hypothesis: There is no statistically significant relationship between project time and cost.

Alternate Hypothesis: There is a statistically significant relationship between project time and cost.

The hypothesis was subjected to Pearson correlation test performed in SPSS statistical software version 15.0 with $\propto=0.05$. The results are presented in Table 7 .

A negative correlation coefficient of -0.739 was obtained between time and cost which is statistically significant. This is in agreement with previous studies on the TCTP $[13,30]$ which found cost to increase as the project was expedited.

Table 7: Pearson Correlation for Time and Cost

\begin{tabular}{llll}
\hline & & Time & Cost \\
\hline \multirow{4}{*}{ Time } & Pearson Correlation & 1 & -0.739 \\
& Sig.(2 tailed) & & 0.002 \\
& $\mathrm{~N}$ & 15 & 15 \\
\multirow{4}{*}{ Cost } & Pearson Correlation & -0.739 & 1 \\
& Sig.(2 tailed) & 0.002 & \\
& $\mathrm{~N}$ & 15 & 15 \\
\hline
\end{tabular}

Sensitivity analysis was performed by adjusting the weight of each objective in (10) and the results presented in Table 8. It was observed that fitness values were not significantly affected by the changes in weights. The developed model is suitable for optimizing time, cost, quality and risk in projects.

\section{CONCLUSION}

The study applied the fuzzy Time-Cost-Quality-Risk Trade-Off model to the magnetic resonance imaging machine installation project. The model was solved using Multiobjective Genetic Algorithm and the Pareto solutions ranked using TOPSIS. The results indicated optimal combination of different execution modes for time, cost, quality, and risk for each of the project activities. The model can be reliably applied in MRI installation projects. The performance of this model could be improved by solving with other evolutionary algorithm techniques and ranking the Pareto optimal solutions using a different multi-criteria decision method. 
Table 8: Sensitivity Analysis

\begin{tabular}{llllll}
\hline Resource option Combination & \multicolumn{3}{l}{ Weight of Objective } & & \multicolumn{2}{c}{ Fitness Value } \\
\hline & $\mathrm{w}_{1}$ & $\mathrm{w}_{2}$ & $\mathrm{w}_{3}$ & $\mathrm{w}_{3}$ & \\
\hline \multirow{2}{*}{112212221212111} & 0.25 & 0.25 & 0.25 & 0.25 & 0.4815 \\
& 0.30 & 0.25 & 0.25 & 0.20 & 0.4780 \\
\hline \multirow{3}{*}{111111111111111} & 0.30 & 0.20 & 0.20 & 0.30 & 0.5777 \\
& 0.25 & 0.25 & 0.25 & 0.25 & 0.4735 \\
& 0.30 & 0.25 & 0.25 & 0.20 & 0.4746 \\
& 0.30 & 0.20 & 0.20 & 0.30 & 0.5767 \\
\hline
\end{tabular}

\section{REFERENCES}

[1] Paryzad B. and Pour, N. S. “Time-Cost-Quality-Risk Trade-off in Giga Projects Using Specific Techniques of Hunting Dolphins", Internal Journal of Industrial and Systems Engineering Vol.22, Number 4, pp. 1504 -1507, 2016.

[2] Khozein, A. Badi, H. Khamaki, A. "Optimization among Time, Cost, Quality and Risk and Introducing the Survival Pyramid", International Journal of Emerging Trends in Engineering and Development Vol. 4, pp. 919 - 926, 2012.

[3] Babu, A.J.G. and Suresh, N. "Theory and Methodology Project Management with Time, Cost and Quality Considerations", European Journal of Operational Research Vol. 88, pp.320 -327, 1996.

[4] Wanderley, M. Menezes, J. Gusmao, C. and Lima, F. "Proposal of Risk Management Metrics for Multiple Project Software Development", Procedia Computer Science 2015, pp.1001 - 1009.

[5] Ugwu, 0. 0. and Attah, I. C. "An Appraisal of Construction Management Practice in Nigeria", Nigerian Journal of Technology Vol. 35 Number 4, pp.754-760, 2016.

[6] Pollack-Johnson, B. "Incorporating quality considerations into Project Time/Cost trade-off analysis and decision making", Engineering Management IEEE transactions Vol. 53 Number 4, $534-542,2006$.

[7] Afshar, A. Kavek, A. and Shoghli, O. "MultiObjective Optimization of Time-Cost Quality Using Multi-Colony Ant algorithm", Asian Journal of Civil Engineering.(Building and Housing) Vol. 8 Number 2pp. 113-124, 2007,

[8] Iranmanesh, M. R. Skandari, and Allahverdiloo, M. "Finding Pareto Optimal Front for the Multi-Mode Time, Cost Quality Trade-off in Project Scheduling", World Academy of Science, Engineering and Technology Vol. 14, pp.512 516, 2008.

[9] Ghodsi, R. Skandari, M. R. Allahverdiloo, M. and Iranmanesh S. H. "A New Practical Model to Trade-off Time, Cost, and Quality of a Project",
.Australian Journal of Basic and Applied Sciences Vol. 3 Number 4, pp. 3741-3756, 2009.

[10] Zhang, H. and Xing, F. "Fuzzy-multi-objective particle swarm optimization for time-cost-quality trade-off in construction", Automation in Construction Vol. 19 Number 8, 1067 - 1075, 2010.

[11] Salmanasnia, A. Mokhtari, H. and Abadi, I. N. K. "A robust scheduling of projects with time, cost, and quality considerations", International Journal of Advanced Manufacturing Technology Vol. 24, Number 9, pp. 170 -184, 2011.

[12] Mokhtari, H. Salmasnia, A. Bastan, M. "Three Dimensional Time, Cost and Quality Trade-off Optimization in Project Decision Making", Advanced Materials Research, pp. 433-440, 2012.

[13] Feng, C. W. and Liu, L. Burns, S. A. "Using Genetic Algorithm to solve construction time-cost tradeoff problems", Journal of Construction Engineering and Management ASCE Vol. 11, pp. 184-189, 1997.

[14] Moselhi, O. and Hassanein, "Optimized scheduling of Linear Projects", Journal of Construction Engineering and Management Vol. 129, Number 6, pp. $664-673,2003$.

[15] Sorrentino, M. "Genetic Algorithm for Construction Time-Cost-Quality Trade-off: A Road Project Case Study", Construction Management Vol. 2, 2013, pp. 163 - 176.

[16] $\mathrm{Hu}, \mathrm{W}$. and $\mathrm{He}, \mathrm{X}$. "An Innovative Time-CostQuality Tradeoff Modeling of Building Construction Project Based on Resource Allocation", The Scientific World Journal, 1-10, 2014.

[17] Crnkovic, J. and Urschel, D. "Managing the Implementation of the Hospital-Based Electronic Medical Records", The Journal of Career Education Principles and Practices Vol. 1, Number 1, pp.1-26, 2010.

[18] Nwaneri, S. C. and Anyaeche, C. O. "An Investigation of Time-Cost-Risk Trade-off in the 
Installation of X-ray Machine Using Response Surface Methodology", Nigerian Journal of Technology Vol. 33, Number 4, pp.482 - 489, 2014.

[19] Nwaneri, S. C. and Anyaeche, C. O. “Optimization of Time-Cost-Quality-Risk Trade-off in a Selected Clinical Engineering Project Using Fuzzy TOPSIS", Proceeding of the Nigerian Institute of Industrial Engineers, pp.129 - 143, 2015.

[20] Ross, T. J. Fuzzy logic with engineering applications. 2nd ed. John Wiley and Sons Ltd, 2004.

[21] Graves, M. J. and Zhu, C. "Basic Principles of Magnetic Resonance Imaging”, Springer, pp. 153$169,2015$.

[22] Alves, C. S. Gomes, M.M.F. and Brasil, L. M. “Project Management for Clinical Engineering Considerations in the evaluation and acquisition of medical equipment for health services in Brazil", World Congress on Medical Physics and Biomedical Engineering, June 7-12, Toronto, Canada, 2015, pp. 1497-1500, 2015.

[23] Condon, P. M. and Robertson, A. R. 'Magnetic resonance imaging: project planning and management of a superconductive M.R.I. installation', Australas Radiology Vol. 33, Number 1, pp. $40-46,1989$.

[24] Xu, J. Zheng, H. Zeng, Z. Wu S. Shen, M. “Discrete time-cost-environment trade-off problem for large-scale construction systems with multiple modes under fuzzy uncertainty and its application to Jinping-II Hydroelectric Project", International Journal of Project Management Vol. 30, pp.950966, 2012.

[25] Fonseca, C. M. and Fleming, P. J. "Genetic algorithms for multiobjective optimization: Formulation, discussion and generalization in Genetic Algorithms", Proceedings of the Fifth International Conference, pp.416-423, 1993.

[26] Azar, S. Reynolds, B. J. and Narayanan S. "Comparison of Two Multiobjective Optimization Techniques with and Within Genetic Algorithms", Proceedings of the ASME Design Engineering Technical Conferences Sept. 12-15, 1999, Las Vegas, Nevada, 1999.

[27] Lai, Y.J. Liu, T. Y. Hwang, C. L. 'TOPSIS for MODM", European Journal of Operations Research Vol. 76, Number 3, pp. 486 - 500, 1994.

[28] Zhou X, Lu M. "Risk evaluation of dynamic alliance based on Fuzzy analytic network process and Fuzzy TOPSIS", Journal of Service Science Management Vol. 5, pp.230-40, 2012.

[29] Jebaseeli, M. E. and Dhayabaran, D. P. Optimal Solution To Fully Fuzzy Time Cost Trade Off Problem. International Journal of Applied Mathematics \& Statistical Sciences. 2(2):27-34, 2013.

[30] Sakellaropoulos, S. Chassiakos, A.P. "Project timecost analysis under generalised precedence relations", Advances in Engineering Software Vol. 35, pp.715-724, 2004. 